\title{
Telaah Kritis Konstruktif Struktur dan Isi Pemahaman Bersama Iman Kristen dalam Perspektif Lutheran
}

\author{
Riris Johanna Siagian \\ Sekolah Tinggi Teologi HKBP, Pematangsiantar, Sumatera Utara, Indonesia \\ ririsjohannasiagian@gmail.com
}

\begin{abstract}
Article History
Received:

19 May 2019

Revised:

May 2019

Published:

31 May 2019

Keywords

(Kata kunci):

Church unity;

Lutherans; The

Common

Understanding of

Christian Faith; the

Communion

Churches in

Indonesia; keesaan

gereja; Lutheran;

PBIK; PGI

Abstract

The Common Understanding of the Christian Faith is the second of Documents on Church Unity, published by the resource department of Indonesia Church Communion. Since this document was published as a document of together in Indonesia in 1984 in Ambon, for churches have a good awareness to get a theology for together in understanding. Nowadays, Indonesia has many problems about how to manage many persons with many different religions. For goal by doing a constructive analysis in Lutherans perspective for this document is very important to prepare this document to be relevant in many situations especially in multicultural, etnic and religion context in Indonesia.

Abstrak

Pemahaman Bersama Iman Kristen (PBIK) adalah dokumen kedua dari lima bagian Dokumen Keesaan Gereja (DKG), yang diterbitkan oleh Litbang Persekutuan Gereja-gereja di Indonesia. Sejak ditetapkan sebagai Pengakuan Iman Bersama di Indonesia pada tahun 1984 di Ambon, bagi gereja-gereja makin tumbuh kesadaran akan pentingnya satu teologi yang dapat dipahami bersama sehingga aksi oikumenis dapat dilakukan dalam kehidupan beragama di Indonesia. Telaah kritis konstruktif dari perspektif Lutheran atas dokumen ini dilakukan terutama untuk mempersiapkan agar dokumen ini tetap relevan menghadapi berbagai persoalan sosial dan kecenderungan di tengah-tengah masyarakat yang multikultural dalam konteks Indonesia.
\end{abstract}

\section{Pendahuluan}

Gereja-gereja di Indonesia dalam penghayatan imannya makin menyadari kompleksnya pergumulan dan tantangan berteologi di Indonesia, hal itu terutama diakibatkan oleh: bangkitnya agama-agama dan budaya lokal, maraknya berbagai tindakan kekerasan, makin dibutuhkannya penghargaan kepada kaum yang terpinggirkan, terutama perempuan dan anak-anak, difabel, LGBT, serta maraknya politik identitas, juga klaim mayoritas dan minoritas, perlunya gereja-gereja berdiri dalam satu payung, dan lain-lain. Hal ini mendorong gereja-gereja di Indonesia untuk merenungkan ulang eksistensinya sebagai sebuah gereja dan panggilannya untuk menjadi garam dan terang. Hal itu sekaligus mendorong terbukanya kesadaran keesaan 
dalam karya untuk bersama-sama meningkatkan saling kesepahaman bersama dalam aksi (oikumene in action).

Dalam kerangka berfikir seperti itulah, Pemahaman Bersama Iman Kristen (PBIK) perlu ditinjau kembali. Hal yang sangat perlu mendapat perhatian adalah latar belakang historis dan teologis yang berbeda di antara gereja-gereja anggota DGI/PGI. Karena itu, perlu adanya upaya yang sengaja untuk duduk bersama, untuk meninjau kembali PBIK secara kritis konstruktif agar relevan dalam menjawab pergumulan teologis dalam konteks Negara Kesatuan Republik Indonesia.

Bagaimana pun sejarah perjalanan kekristenan di dunia dengan seluruh pergumulan dan tantangannya dapat digunakan menjadi pembelajaran yang sangat berharga dalam merumuskan kerangka berfikir teologis yang dapat dipahami dan diterima secara bersama dalam pemikiran dan tindakan. Tentu saja, refleksi teologis sangat diperlukan untuk melihat sejauh mana, apa dan bagaimana kesaksian gereja pada masa lampau, dan itu berguna sebagai modal untuk melangkah jauh ke depan.

Gereja-gereja sebagai anggota Lutheran, Calvinis, Injili, Pentakostal/NeoPentakostal/Karismatik, meskipun masing-masing memiliki keterikatan tertentu dengan berbagai aliran gereja itu, namun tidak tertutup kemungkinan gereja secara sendirisendiri memiliki implementasi yang berbeda di lapangan. Huria Kristen Batak Protestan (HKBP) juga memiliki sejarah unik ketika sepakat untuk mengikatkan diri menjadi anggota Lutheran.

Ada pun pemikiran kritis konstruktif ini disampaikan dengan pendekatan Teologi Agama-agama di mana Teologi Agama-agama merupakan satu cabang dari Teologi Sistimatika. Teologi Agama-agama tidak saja berupaya mencermati keberadaan agama-agama, tetapi bagaimana agama mempengaruhi masyarakat dan bagaimana agama itu sendiri dihidupi oleh masing-masing penganutnya. Oleh karena itu, berbagai ilmu pengetahuan terutama Sosiologi dan Filsafat dimungkinkan untuk digunakan sebagai kerangka analisis untuk mendudukkan persoalan implementasi hidup beragama dalam realitas hidup sehari-hari.

Telaah kritis berkaitan dengan tema-tema dalam PBIK dilakukan dengan mengedepankan nats-nats tertentu dan bagaimana nats-nats yang sama itu dipahami secara berbeda dalam tingkat implementasi. Tentu saja, implementasi yang berbeda itu tidak hanya berkaitan dengan pemahaman akan nats itu sendiri, tetapi terutama sangat dipengaruhi oleh latar belakang sejarah, teologis, dan sosiologis serta cara berteologi yang berbeda di antara masing-masing gereja.

Pemahaman demikian diharapkan akan dapat menemukan satu rantai yang hilang (missing link) dari hidup keagamaan kita sebagai satu bangsa Indonesia. Hal ini sekaligus mendorong agar penafsiran Alkitab berkaitan dengan nats tertentu tidak dilakukan secara parsial melainkan dilakukan secara holistik, dengan mengedepankan Tuhan Allah yang telah menyatakan diri-Nya melalui Alkitab. Tentu saja pemikiran ini telah melalui satu studi dan refleksi yang panjang, sehingga gagasan yang diajukan tidak semata-mata dari subjektifitas penulis. 


\section{Metode}

Penelitian ini merupakan telaah atau review terhadap konsep Pemahan Bersama Iman Kristen (PBIK) yang terdapat dalam Dokumen Keesaan Gereja dari perspektif Lutheran. Metode yang digunakan adalah analisis deskriptif terhadap poin-poin yang ada dalam PBIK itu sendiri.

\section{Pembahasan}

\section{Kerangka PBIK}

Ada pun struktur Pemahaman Bersama Iman Kristen (PBIK) diawali dengan pokok tentang Tuhan Allah (Bab I) dan diakhiri dengan pokok tentang Alkitab (Bab. VII). Dan pokok-pokok penting lainnya tentang: Penciptaan dan Pemeliharaan, Manusia, Penyelamatan, Kerajaan Allah dan Hidup Baru, Gereja berada di antaranya. Secara khusus, point yang terbanyak mendapat perhatian adalah point tentang gereja.

Dalam hal ini, penulis ingin menyampaikan adanya kerancuan berfikir dalam hal struktur PBIK itu sendiri. Sebab, sebenarnya pembahasan tentang Tuhan tidak ada bedanya dengan pembahasan tentang topik-topik lainnya. Semua pergumulan dan pembahasan tentang tema-tema besar itu seharusnya bersumber dan berada di bawah payung yang sama, yakni Alkitab. Maka, Alkitablah yang seharusnya memayungi dan mencerahi semua pemahaman tentang tema-tema yang digali itu. Oleh karena itu, Alkitab harus ditempatkan dalam bab I.

Dalam PBIK, pemahaman tentang Alkitab pada Bab VII, alinea 1, dikatakan: “Alkitab yang terdiri dari Kitab Perjanjian Lama dan Kitab Perjanjian Baru merupakan kesaksian yang menyeluruh mengenai Allah yang menyatakan diri, kehendak dan karya penciptaan, pemeliharaan dan penyelamatan-Nya kepada manusia, dan juga mengenai jawaban manusia terhadap-Nya. Kesaksian yang menyeluruh ini berpusat pada Yesus Kristus "Firman yang menjadi manusia" (Yoh. 1:14). Dengan demikian, pemahaman mengenai isi Alkitab termasuk pemahaman atas bagian-bagiannya harus selalu dilihat sebagai satu kesatuan."1

Kalimat yang digaris tebal di atas menegaskan bahwa Alkitab memuat keseluruhan tentang Allah yang menyatakan diri-Nya, kehendak-Nya, karya penciptaan dan pemeliharaan-Nya atas dunia dan seluruh manusia. Eksistensi Allah yang menyatakan diri itulah, sebagaimana Ia dikenal, dipahami dan terinternalisasi dalam diri para Nabi dan Rasul. Itulah yang seharusnya menjadi dasar kesaksian seluruh orang percaya. Jadi, bukan bagaimana para Nabi, Imam dan Rasul mengenal Allah itu. Tetapi, DIA adalah Allah sebagaimana Dia menyatakan diri-Nya (Yeh. 22:44).

Di dalam dan melalui diri para murid-Nya, Allah yang telah menyatakan diri itu disaksikan seluruh orang percaya. Orang percaya menjadi mengalami 'eksternalisasi' tentang Allah itu sendiri. Dan hasil dari eksternalisasi itu akan muncul sebagai bagian

${ }^{1}$ Persekutuan Gereja-gereja di Indonesia, Dokumen Keesaan Gereja Persekutuan Gereja-gereja di (DKG-PGI), (Jakarta: BPK Gunung Mulia, 2015), 116. 
dari kesaksian, suara kenabian. Sehingga para murid tidak menyatakan pengenalan dan gagasan pemikiran mereka tentang Allah.Tetapi bersaksi tentang Allah yang telah menyatakan diri lewat mereka.

Sebagai perbandingan, kondisi kerancuan berfikir seperti yang terjadi dalam PBIK, sebenarnya juga terjadi di dalam konfesi HKBP.Dalam Konfesi HKBP berbicara 'Tentang Allah,'(pasal 1) dilanjutkan dengan 'Tentang Allah yang Tiga-Esa' (pasal 2); dan 'Pekerjaan Kepribadian Allah Bapa Yang Tiga-Esa' (pasal 3). Lalu bagian berikut berbicara 'Tentang Firman Allah' (pasal 4). Padahal pada alinea terakhir dari pasal 4 jelas dikatakan bahwa: "Hanya Alkitablah awal dan akhir segala pemikiran, pengetahuan dan usaha di dalam gereja dan bagi setiap orang percaya. Dengan ajaran inikita tolak semua kepandaian dan kebijaksanaan manusia yang bertentangan dengan Firman Allah (Ams. 3:5; Mzm. 111:10)."2 Bagian terakhir ini menjadi benar dan tepat, justru kalau ia ditempatkan pada bab pertama sekali, sehingga seluruh pemikiran dan pembahasan tentang pokok mana saja, harus bersumber dari Alkitab.

Sejarah kekristenan dunia telah membuktikan hal itu, di mana muncul pemahaman dan refleksi teologis yang berbeda, yang menempatkan gereja Katolik dan Martin Luther berada dalam ketegangan-ketegangan. Analisis kritis dan refleksi teologis atas kehidupan bergereja ketika itu terkait pandangan Martin Luther tentang Perjamuan Kudus, di mana pelaksanaan perjamuan kudus sebagaimana ditetapkan oleh Tuhan Yesus adalah dengan memberikan roti dan anggur sebagai lambang dari kehadiran tubuh dan darah Kristus. Dan keduanya diberikan kepada orang yang berdosa, dan yang percaya tentang pengampunan dosa di dalam Yesus Kristus. ${ }^{3}$

Namun oleh para imam dibuat peraturan berbeda. Para imam menerima roti dan anggur dalam perjanjian perjamuan kudus, sedangkan kepada warga jemaat hanya diberikan roti. Alasan yang dimunculkan bahwa secara iman jemaat lebih banyak dosanya, sehingga mereka selayaknya hanya diberi satu bagian dari perjanjian perjamuan kudus. Sementara para imam lebih kudus dan karenanya layak memperoleh keduanya. Hal ini tentu saja berbanding terbalik dengan tujuan penetapan perjamuan kudus itu sendiri oleh Tuhan Yesus, bahwa pemberian roti dan anggur ditujukan kepada orang yang memohon pengampunan dosa, dan yang telah mengaku dosanya. ${ }^{4}$ Dengan kata lain, anugerah perjamuan kudus milik setiap orang percaya yang memohon keampunan dosa, tanpa kecuali.Kenyataannya, yang terlihat adalah superioritas para imam. Ini juga bagian dari kesalahan menempatkan sebagai apa Alkitab dan otoritasnya yang sahih. 5

\footnotetext{
${ }^{2}$ Huria Kristen Batak Protestan, Pengakuan Iman HKBP: Konfesi 1951 \& 1996 (Pearaja Tarutung: Kantor Pusat HKBP, 2000), 58.

${ }^{3}$ Martin Luther, Three Treatises: The Babylonia Captivity of the Church, translated by A.T.W Steinhauser, revised by Frederick C. Ahrens and Abdel Ross Wentz, vol. 36 (Philadelpia: Fortress Press, 1959), 135.

${ }^{4}$ Ibid., 136.

${ }^{5}$ Riris Johanna Siagian, Gereja dan Kekuasaan: Menuju Eklesiologi HKBP yang Kontekstual (Pematangsiantar: Lembaga Bina Warga HKBP dan Sekolah Pendeta HKBP, 2017), 36-37.
} 
Jika logika ini diteruskan, maka sebenarnya para imam yang nota bene orang-orang kudus Allah justru telah menempatkan dirinya sebagai orang-orang yang paling berdosa dari seluruh warga jemaat yang berdosa lainnya. ${ }^{6}$ Perbedaan cara pandang itu, kemudian mendorong lahirnya kelompok Protestan. Dari sini, ini menjadi tegas bagi kita, bukan bagaimana pemahaman kita tentang Allah, tetapi bagaimana Allah menyatakan diriNya. Menurut hemat penulis, kerangka berfikir seperti ini yang coba digaungkan kembali oleh Martin Luther dengan munculnya slogan back to the Bible. Dari sini dapat dipahami bahwa Alkitab harus menjadi satu-satunya sumber dasar dan utama. Penegasan demikian juga diturunkan dalam konfesi HKBP. ${ }^{7}$ Karenanya, Alkitab memiliki otoritas tertinggi.

\section{Allah}

Pemahaman PBIK tentang Allah menyatakan: "Tuhan itu Allah kita, Tuhan itu Esa (Ul. 6:4). Tidak ada Allah lain selain Dia (Kel. 20:3; Ul. 5:7). Dialah Allah yang telah menciptakan langit dan bumi serta seluruh isinya, dan yang telah memeliharanya hingga kesudahan alam (Kej. 1:2; Mzr. 24:1-2; 89:12; 104:1, dst; Kol. 1:16)."8

Pernyataan itu menegaskan hanya ada satu Allah, satu-satunya Allah, yang telah menciptakan langit dan bumi. Hal ini juga diakui oleh gereja-gereja Lutheran, seperti halnya HKBP, dikatakan: "Allah adalah Esa, tak bermula dan tak berkesudahan...Ia menggenapi langit dan bumi, Maha Kudus, Maha Kasih."9 Dan dalam bagian tentang Allah Tri Tunggal, Allah Bapa yang Tiga Esa, dikatakan: "Allah Bapa menjadikan, memelihara dan memerintah segala sesuatu yang kelihatan dan tidak kelihatan."10

Kedua pemahaman itu sejajar ini, baik PBIK dan HKBP sebagai gereja Lutheran. Pemahaman keyakinan ini menegaskan bahwa Allah yang Esa itu tak bermula dan tak berkesudahan. Alkitab juga tidak menjelaskan kapan Allah itu mulai ada, dan hingga kapan Ia akan berakhir, tidak ada juga yang tahu kapan dunia akan berakhir. Iman Kristen mengatakan ketika Yesus datang ke dunia ini, ia akan menghakimi orang yang benar dan salah. Tetapi kapan itu? Tidak seorang pun yang tahu, bahkan malaikatmalaikat sorgawi pun tidak tahu.

Dalam hal ini, menarik mencermati pemahaman Batak tentang penciptaan manusia sebagaimana termuat dalam mitos-mitos Batak. ${ }^{11}$ Penggunaan mitos sebagai bahan studi sudah banyak dilakukan, di mana mitos itu sendiri memuat perintahperintah moral yang disampaikan dan harus dilakukan oleh setiap penganut, di mana perintah-perintah itu bersifat mengikat dan dipahami sebagai ajaran dalam keagamaan

\footnotetext{
${ }^{6}$ Ibid., 38.

${ }^{7}$ Huria Kristen Batak Protestan, Pengakuan Iman HKBP: Konfesi 1951 \& 1996, 126-127.

${ }^{8}$ Persekutuan Gereja-gereja di Indonesia, Dokumen Keesaan Gereja Persekutuan Gereja-gereja di Indonesia (DKG-PGI), 102.

${ }^{9}$ Huria Kristen Batak Protestan, Pengakuan Iman HKBP: Konfesi 1951 \& 1996, 54.

${ }^{10}$ Ibid., 55.

${ }^{11}$ Band. Clifford Gertz, The interpretation of Culture (USA: Basic Books, 1973), 112.
} 
Batak. ${ }^{12}$ Orang-orang Batak sendiri dengan kerangka berfikirnya yang khusus telah ada jauh sebelum kekristenan masuk ke tanah Batak. Sedangkan ajaran Batak telah lebih dahulu ada baru ajaran Kristen masuk ke tanah Batak. Baru tahun 1861 terjadi pembabtisan orang Kristen yang pertama, dan sekaligus diperingati sebagai hari lahirnya Gereja Batak Raya. ${ }^{13}$

Hal itu dituliskan dengan baik oleh Waneck: ${ }^{14}$ "Apa yang dimengerti oleh Batak mengenai muasal manusia dan bumi, kata orang: Mulajadi na Bolon telah menciptakan segala sesuatu..." 15 Mulajadi na Bolon dipahami sebagai Tuhan dalam pemahaman keyakinan Batak. Kalimat ini tentu tidak menunjuk pada seorang Warneck yang sedang menjelaskan tentang manusia dalam pemikiran Batak. Kalimat "kata orang..." ini menegaskan bahwa orang Batak sendirilah yang sedang dinyatakan di situ. ${ }^{16} \mathrm{Hal}$ ini dapat dimengerti, bahwa dalam pemahaman keyakinan orang Batak sendiri menegaskan bahwa dunia ini dan segala sesuatunya diciptakan oleh Mulajadi na Bolon, Tuhan Debata yang Besar, yang Agung. Keyakinan seperti itu sudah ada jauh sebelum kekristenan masuk ke tanah Batak. Dan penegasan keyakinan seperti itu tersimpan dalam banyak mitos. Penggunaan mitos dalam sastra-sastra keagamaan yang menunjuk pada kitab-kitab keagamaan biasa digunakan dalam komunitas keagamaan. Tidak terkecuali dalam keagamaan Batak. Alkitab Perjanjian Lama sendiri memuat beberapa mitos, khususnya tentang cerita penciptaan. Dalam agama Hindu dan Budha, upaya mengumpulkan mitos-mitos yang dikenal umum di tengah-tengah masyarakat biasa dilakukan, untuk digunakan sebagai sumber pengajaran.

Ir. Soekarno, ketika berbicara di hadapan panitia 9 dalam pidatonya dalam upayanya untuk menggolkan Pancasila sebagai dasar Negara menyampaikan argumentasi kritis dan sekaligus keyakinan religiusnya bahwa Indonesia terdiri dari berbagai agama dan aliran kepercayaan. Kenyataan seperti itu yang kemudian dituangkan dalam sila-sila dari Pancasila, secara khusus sila I, Ketuhanan yang Maha Esa. ${ }^{17}$ Hal Ketuhanan yang Maha Esa ini sejalan dengan keyakinan Kristen Protestan, juga sejalan dengan keyakinan agama Batak, yang sekarang diteruskan oleh Parmalim, dan tentunya sesuai dengan keyakinan banyak agama lain di bumi NKRI. Dengan meletakkan pemahaman sedemikian, faktanya upaya ini mendorong terbukanya ruang untuk berdiskusi dan sharing antar pemeluk agama. Dalam hal ini secara khusus agama Kristen dan Batak, yang masih tetap diwarisi oleh penganut aliran kepercayaan

\footnotetext{
${ }^{12}$ Riris Johanna Siagian, Sahala Bagi Pemimpin: Dulu dan Kini, (Pematangsiantar: Lembaga Bina Warga HKBP dan Sekolah Sekolah Pendeta HKBP dan STT-HKBP, 2018), 53.

${ }^{13}$ Lih. Harry Parkin, Batak Fruit of Hindu Thought, 14-51. Band: Huria Kristen Batak Protestan, Almanak HKBP (Pearaja Tarutung: Kantor Pusat HKBP 20119), 559.

${ }^{14}$ Warneck adalah seorang misionaris berkebangsaan Jerman, dalam mitos ini tertulis tahun 1911. Tentu saja, mitos-mitos itu telah hidup jauh lama mengingat tradisi dan komunitas Batak sudah ada jauh sebelumnya. Parkin menulis, sebuah inskripsi Tamil memuat tentang Labu Tua di Barus, di mana terdapat pedagang-pedagang India bermukim sekitar 1.500 orang di di Barus tahun 1088.

${ }^{15}$ Anicetus B. Sinaga, Allah Tinggi Batak Toba (Yogyakarta: Kanisius, t.th.), 241-247.

${ }^{16}$ Siagian, Sahala Bagi Pemimpin: Dulu dan Kini, 207.

${ }^{17}$ Soekarno, Di Bawah Bendera Revolusi (Jakarta: Panitya Penerbit, 1965), 101.
} 
Parmalim. Hal itu dimungkinkan dan tentu sangat diharapkan dalam konteks masyarakat Indonesia yang multi etnis dan multi kultural, multi agama.

\section{Penciptaan dan Pemeliharaan}

Secara tegas, PBIK menuliskan bahwa: "Alam semesta, langit dan bumi serta segenap isinya, baik yang kelihatan maupun yang tidak kelihatan, adalah milik ciptaan Allah (Kej. 1-2; Mzr. 24:1-2; 89:12; Yes 44:24; Yer. 27:5; Kol 1:16).” Pernyataan ini menegaskan bahwa segala sesuatu dan semua yang ada di atas langit maupun yang ada di bawah langit adalah milik ciptaan Alah. Dengan demikian, tidak ada yang tidak bersumber dari Allah. Kepemilikan Allah ini mutlak dan mengikat.

Melalui berita penciptaan dalam kitab Kejadian menegaskan bahwa tugas pemeliharaan disampaikan kepada manusia. Ada pun pelaksanaan tugas pemeliharaan itu sangat tergantung kepada perilaku hidup dari setiap manusia, agar tugas mulia itu tidak diselewengkan, sebab jika demikian tugas memelihara akan berubah menjadi menguasai. Dalam kerangka itu, intitusi keagamaan dan institusi pemerintah juga memiliki peran yang sangat kuat dalam menjamin tugas-tugas pemeliharaan dapat berlangsung dengan baik. Negara Republik Indonesia juga menetapkan hal ini dalam UUD 1945, pasal 33:3, yang berbunyi: "bumi, air dan kekayaan alam yang terkandung di dalamnya dikuasai oleh negara, dan dipergunakan sebesar-besarnya untuk kemakmuran rakyat."

Hal ini menegaskan bahwa negara menjamin tidak boleh ada berbagai tindakan eksploitasi, pencurian, penjarahan dan lain sebagainya terhadap alam untuk digunakan bagi kepentingan diri sendiri dan kelompok. Dalam kenyataannya, banyak hutan gundul sehingga mengakibatkan erosi tanah dan banjir di mana-mana.Pengerukan tanah, batu, gunung dan lainnya dengan tidak bertanggungjawab telah mengakibatkan kerusakan lingkungan yang parah, musnahnya kehidupan ratusan bahkan ribuan tanamtanaman langka dan satwa langka dari bumi Indonesia merupakan satu bukti bahwa tugas pemeliharaan tidak berlangsung dengan baik dan seharusnya.

Upaya pemulihan terhadap bumi, air dan kekayaan alam lainnya mutlak diperlukan. Namun lebih dari itu, bagaimana membangun spiritualitas yang mendorong kedekatan manusia dengan alam, dan hidup bersama dengan alam. Berbagai budaya lokal yang sangat mengutamakan kearifan lokal justru terasa lebih dekat dengan alam. Spiritualitas yang sangat mengedepankan cara-cara budaya yang jauh dari ketamakan dan pementingan diri sendiri.

Teologi Batak memerlihatkan air, gunung, batu dan lain sebagainya dapat menjadi sarana perjumpaan dengan Tuhan. Bahkan bahwa hal-hal yang sangat kecil dari alam pun, seperti ulat memiliki fungsi yang luar biasa dalam kehidupan manusia. ${ }^{18}$ Pada akhirnya, hal ini pun terkait dengan ketaatan dalam panggilan untuk tugas pemeliharaan itu.

\footnotetext{
${ }^{18}$ Siagian, Sahala Bagi Pemimpin: Dulu dan Kini, 207-252.
} 


\section{Manusia}

Dalam PBIK terdapat pengakuan bahwa "manusia diciptakan Allah menurut gambar/citra-Nya (Kej. 1:26-27). Manusia diciptakan sebagai laki-laki dan perempuan dengan martabat yang sama (Kej. 1:27), dan dikaruniai tugas mandat untuk beranak cucu dan memenuhi bumi serta untuk menguasai, mengusahakan, dan memelihara seluruh ciptaan Allah (Kej. 1:26-28; 2:15). Untuk dapat melaksanakan tugas dan mandat itu, Allah memperlengkapi manusia dengan akal budi dan hikmat serta memahkotainya dengan kemuliaan, hormat, dan kuasa (Mzr. 8:6-7). Manusia diciptakan dalam kesatuan tubuh, jiwa roh, sehingga ia dipanggil untuk memelihara kehidupan secara jasmani dan rohani dalam rangka pemenuhan tanggung jawabnya kepada Allah (Kej. 2:7; 1 Kor 3:16; 6:17-20; 1 Tes 5:23; Yak. 2:26) ..."

Dalam hal ini terdapat beberapa pokok pikiran yang masing-masing membutuhkan bahasan yang panjang lebar sesuai dengan tujuan dan maksud penciptaan manusia itu sendiri.

\section{Imago Dei, sebuah Ketaatan}

Penciptaan manusia menurut gambar dan citra Allah menunjuk pada penciptaan sebagai yang Imago Dei. Hal kesegambaran Allah itu tidak saja menunjuk pada wajah Allah yang secara fisik terlihat terdiri dari dua bola mata, dua lubang hidung, dua telinga dan satu mulut. Tetapi juga terutama menunjuk pada citra Allah yang sebenarnya. Citra Allah, siapa, apa, dan bagaimana Allah itu yang dipresentasikan melalui diri Yesus Kristus.

Menarik mengamati pengakuan iman Huria Kristen Batak Potestan tentang manusia, dikatakan: "Manusia adalah ciptaan Allah, laki-laki dan perempuan, menurut gambar-Nya, sama dengan perangai-Nya (Imago Dei)." ${ }^{19}$ Di sini, pemaknaaan kata Imago Dei menjadi utuh dan holistik ketika itu menunjuk pada perangai Allah. Oleh karena itu citra Allah dalam hal ini dapat dipahami berkaitan dengan eksistensi Yesus dalam seluruh karya-Nya di dunia. Melalui kehadiran Yesus sendiri di dunia, manusia boleh belajar dari Yesus tentang bagaimana Ia menggunakan akal budi, hikmat, kemuliaan, hormat dan kuasa.Hal yang juga sangat mendapat tekanan, yakni kesatuan tubuh, roh dan jiwa.

Saya ingin memulai dari bagian tentang kesatuan tubuh, roh dan jiwa. Yesus Kristus sebelum memulai karya-Nya di dunia, Ia terlebih dahulu berpuasa selama 40 hari 40 malam. Dan dalam proses itu, iblis datang mencobai Dia dengan janji-janji yang manis dan menawarkan seluruh keindahan dunia, seluruh kuasadan kemuliaan dunia, dengan satu syarat asal Yesus mau menyembah kepadanya (Mat. 4:1-11; Mrk. 1:12-13; Luk. 4:1-13). Tetapi respons Yesusjustru menegaskan ketaatan-Nya kepada Bapa-Nya (Mat. 4:10).

Kata kunci dari apa yang sedang Yesus perlihatkan adalah ketaatan. Kata itulah yang menjadi kontrol dan pengikat antara kesatuan tubuh, roh, dan jiwa-Nya dengan

\footnotetext{
${ }^{19}$ Huria Kristen Batak Protestan, Pengakuan Iman HKBP: Konfesi 1951 \& 1996, 128.
} 
bapa di surga.Pemanggilan manusia untuk memenuhi tugas dan tanggung jawabnya kepada Allah hanya mungkin terlaksana dalam ketaatan yang demikian.Hal ini perlu dikritisi secara serius karena manusia sering memahami tubuh terpisah dari roh dan jiwanya.

Pemahaman tentang tubuh, roh dan jiwa juga merupakan satu perdebatan yang panjang dalam dunia filsafat, di mana manusia dipandang terdiri dari tubuh, roh dan jiwa. Namun dalam hal ini terdapat dualisme, di mana tubuh dipandang berkaitan dengan hal-hal yang jasmani sedangkan roh dan jiwa dipandang berkaitan dengan halhal yang rohani.Tubuh manusia pun bersifat sementara, sedang roh dan jiwa bersifat kekal. ${ }^{20}$ Jiwa dan badan dipandang sebagai dua kenyataan yang berbeda, di mana badan akan mati, tetapi jiwa bersifat kekal (lebih jauh hal ini berkaitan dengan tema-tema tentang hidup setelah mati). Kesatuan tubuh, roh dan jiwa mengartikan bahwa keduanya hadir secara eksis dalam diri seorang manusia. Ketidakseimbangan antara tubuh, roh dan jiwa inilah yang mengakibatkan manusia jatuh ke dalam dosa.

Namun demikian, di dalam diri Yesus keseimbangan itu tampak menonjol, karena Ia berusaha menghidupi relasinya dengan Bapa dalam ketaatan. Hal ini pun sangat terasa dalam pergumulan Yesus ketika Ia berada di bukit getsemani, secara khusus dalam pergumulan batin-Nya dalam berperang dengan diri-Nya sendiri. Alkitab mencatat betapa Yesus sangat bergumul sekali, dikatakan: "Hatiku sangat sedih, seperti mau mati rasanya..." (Mat. 26:38; Mrk 14:34), Yesus juga merasa sangat ketakutan dan makin bersungguh-sungguh berdoa. Peluh-Nya menjadi seperti titik-titik darah yang bertetesan ke tanah (Luk. 22:44).

Di sini tubuh Yesus mengalami suatu perasaan mau mati, ketakutan yang amat sangat, dan peluhnya menetes seperti titik-titik darah. Tetapi tubuh yang menahan derita amat sangat itu selaras dengan penyerahan jiwanya melalui doa yang sungguh-sungguh. Pergumulan terbesar antara tubuh dan jiwa Yesus, tergambar melalui apa yang diungkapkan-Nya, "Ya Abba, ya Bapa, tidak ada yang mustahil bagi-Mu, ambillah cawan ini dari pada-Ku, tetapi janganlah apa yang Aku kehendaki, melainkan apa yang Engkau kehendaki.” (Mat. 26:39; Mrk. 14:36; Luk. 22:42).

Perasaan-perasaan jasmani yang dialami Yesus itu bersifat manusiawi dan biasadialami manusia dalam hidup sehari-hari. Kata-kata Yesus yang menyerahkan hidup-Nya itulah yang membuat ketaatan-Nya menjadi sempurna, ketika Dia mengatakan: “... tetapi jangan kehendak-Ku Bapa, kehendak-Mulah yang jadi.” Di sini Yesus tidak sedang memperlihatkan akal budi, tetapi dalam seluruh pergumulan batinNya, Yesus menampilkan hikmat dari diri-Nya sendiri. Dan ketaatan seperti itulah yang dipertontonkan Yesus hingga kematian-Nya di kayu salib.

\section{Sahala, Spiritualitas dalam ketaatan}

Spiritualitas dalam ketaatan diperoleh dalam relasi yang kontemplatif dengan Tuhan Allah. Kemampuan tubuh manusia untuk menahan tekanan, derita dan sengsara

\footnotetext{
${ }^{20}$ Harun Hadiwijono, Sari Sejarah Filsafat Barat (Yogyakarta: Kanisius, 1980), 42.
} 
itu terbatas. Tetapi roh dan jiwa akan memberi spirit yang luar biasa untuk menguatkan manusia untuk tetap bertahan. Yesus sendiri pun sudah mengingatkan manusia, bahwa roh memang penurut, tetapi daging lemah (Mat. 26:41; Mrk. 14:38, Luk. 22:46). Dan spirit, energi yang luar biasa itu diperoleh dalam kontak dan relasi yang terus-menerus dengan Allah Bapa, melalui perenungan dan doa, sebagaimana Yesus perlihatkan melalui doa yang bersungguh-sungguh.

Pemaknaan Imago Dei sebagai meniru perangai Allah menunjukkan bahwa pada dasarnya, perangai yang Imago Dei itu adalah perangai dalam keseluruhan ketaatan kepada Allah. Oleh karena itu, karakter manusia yang sedemikian adalah karakter yang memiliki hubungan yang akrab dan relasi yang kuat di dalam Allah. Dari sebuah studi dan refleksi akan berbagai kenyataan manusia sekarang ini, disimpulkan bahwa menjadi manusia beragama bukanlah bagaimana seseorang memeluk satu agama tertentu. Tetapi yang pertama dan terutama adalah bagaimana seorang manusia itu menghidupi keyakinan keagamaannya yang kemudian membentuk perilakunya sehari-hari. Satu istilah yang belakangan ini muncul, disebut dengan sahala.

Kata sahala merupakan kata asli dari bahasa Batak, bermakna wibawa plus, karisma plus. Di sini, kata sahala dipahami sebagai "substansi tertinggi dari hidup beragama." ${ }^{21}$ Sahala itu sendiri terbentuk karena: Spiritualitas Unggul (Excellent Spirituality), Kualitas Unggul (Excellent Quality), Karakter Unggul (Excellent Character). ${ }^{22}$ Seseorang yang memiliki sahala yang tinggi akan menampilkan dari dirinya karakter yang positif, karakter yang membawa kebaikan-kebaikan dan mendatangkan kehidupan bagi orang lain. Karakter itu sendiri dihasilkan dari pemaknaan hidup dalam ketaatan kepada Tuhan yang dipuja. Upaya mencermati secara mendalam tokoh-tokoh Batak sejak jaman dahulu hingga sekarang, terutama mereka, yang dalam masa kepemimpinan di tengah-tengah gereja dan masyaraat memiliki peran-peran strategis dan menentukan.

Melalui studi itu lahirlah teologi sahala. Hal yang menarik melalui kaca mata sahala memperlihatkan bahwa setiap orang, meski berbeda agama, suku, ras, bahasa, dan lain sebagainya. Tetapi jika setiap orang itu menghidupi nilai-nilai tertinggi dari keagamaannya, maka ia akan tampil marsahala, memiliki wibawa plus. Karena tidak ada agama yang mengajarkan perbuatan-perbuatan kejahatan, curang, menipu, memutarbalikkan fakta, dan lain sebagainya. Meski banyak persoalan yang dihadapinya, seberat apa pun itu, maka dari dirinya sendrii akan tercetus nilai-nilai ideal, dan menampilkan dirinya yang cemerlang.

Orang-orang yang memiliki sahala tinggimemerlihatkan di dalam dirinya terdapat nilai-nilai ideal, dan orang-orang seperti itulah yang kemudian menonjol dalam tataran kepemimpinan, sebagai orang yang: berspiritualitas (martondi), berintegritas (satu kata dan tindakan, sada hata nang pambahenan), dapat dipercaya, (haposan), Mendengar

\footnotetext{
${ }^{21}$ Riris Johanna Siagian, Agama, Spiritualitas Kepemimpinan, Gereja dan Masyarakat, (Pematangsiantar: Lembaga Bina Warga HKBP dan Sekolah Pendeta HKBP, 2019), 5.

${ }^{22}$ Siagian, Sahala Bagi Pemimpin: Dulu dan Kini, 90-143.
} 
dengan hati (roha na manangihon), bijaksana (marbisuk), visioner (marpanatapan tu jolo), Mengayomi/melindungi (marorot). ${ }^{23}$ Dengan pendekatan teologi sahala, akan membuka ruang dalam berdiskusi dan sharing yang lebih jauh. Karena pemaknaan sahala tidak dibatasi oleh agama apa yang dianut. Agama, dogma, aliran keagamaan dapat saja membatasi gerak persekutuan orang-orang percaya. Tetapi orang-orang yang berbeda, agama, ras, suku itu sangat mungkin diikat dan bersatu melalui pendekatan teologi sahala. Ini menjadi perjuangan kita bersama.

Sejauh mana manusia itu menghidupi keyakinan-keyakinan keagamaannya, dan diperlihatkan melalui kasih dan tindakan-tindakan kebaikan. Perbuatan curang, kolusi, korupsi, nepotisme, termasuk menghujat orang lain yang berbeda agama dengannya menegaskan pola-pola hidup demikian bukan datang dari Tuhan Allah. Pemaknaan tentang Tuhan dari sudut pandang sendiri, dan dengan logika berfikir manusia semata menjadikan manusia itu sendiri tidak berbeda dengan orang Farisi dan ahli Taurat, yang mengetahui banyak hal tentang Tuhan Allah, tetapi tidak memegang kepercayaannya itu, apalagi tidak menghidupinya dalam spiritualitas yang terus tertuju pada Allah.

\section{Ketaatan, dalam Relasi Perempuan dan Laki-laki}

Komitmen dan ketaatan untuk hidup dalam panggilan sebagai Imago Dei mendatangkan penghargaan atas harkat dan martabat manusia satu sama lain, terutama dalam relasi sosial antara perempuan dan laki-laki. Kesegambaran dengan Allah itu memandang bahwa perempuan dan laki-laki adalah para murid yang sejak awal berada di sekeliling Yesus. Alkitab menyaksikan bahwa perempuan maupun laki-laki tidak bisa bekerja sendiri, keduanya pun tidak bisa hidup terpisah. Karena keduanya memiliki kekhususan yang saling menopang dan menghidupkan. Berbagai sifat yang sering diperlihatkan sebagai sifat feminin dan maskulin juga terlihat dari sosok seorang Yesus.

Relasi perempuan dan laki-laki dianggap memliki keunggulan yang sama dan saling melengkapi, keduanya berada dalam posisi yang setara, partnership sebagaimana, partnership dalam sex. ${ }^{24}$ Ketidaktaatan membuat relasi itu sendiri menjadi timpang dan bersifat 'menguasai dan dikuasai.' Hal ini sekaligus memerlihatkan keterbatasan manusia itu menggunakan akal budi dan hikmatnya. Oleh karena itu pemaknaan terhadap kuasa itu yang perlu dijernihkan.

Kuasa dalam arti otoritas yang dimaksud di sini, berasal dari bahasa Yunani exousia, yang menurut para ahli merupakan suatu hak yang diberikan (given by) ${ }^{25}$, bukan otoritas yang dimiliki sendiri. Tanpa di dalam ketaatan pada panggilan masingmasing, maka, implementasi kuasa akan membuat manusia itu mengalami banyak derita dan sengsara. Manusia sebagai Imago Dei pun menjadi kehilangan kemuliaan Allah.Penghargaan pada hak-hak azasi manusia menjadi terabaikan dan tercederai. Semuanya terjadi sebagai bagian dari ketidaktaatan. Oleh karena itu Alkitab harus

\footnotetext{
${ }^{23}$ Siagian, Agama, Spiritualitas Kepemimpinan, Gereja dan Masyarakat, 179-205.

${ }^{24}$ Letty M. Russel, Growth in Partnership (Philadelphia: Westminster Press, 1981), 47-48.

${ }^{25}$ Max Weber, Economy and Society, (London: University of California Press, 1925/1978), 53.
} 
menjadi sumber dan cerminan yang utama, sehingga ketimpangan-ketimpangan dalam relasi sosial antara perempuan dan laki-laki dapat dieliminir sebaik mungkin.

\section{Penyelamatan}

PBIK menyebutkan bumi menjadi rusak dan penuh kekerasan karena manusia telah jauh ke dalam dosa. Namun karena kasih Allah, manusia beroleh keselamatan. Dikatakan, "Keselamatan itu telah mencapai manusia karena Yesus Kristus yang walaupun dalam rupa Allah tidak menganggap kesetaraan-Nya dengan Allah itu sebagai milik yang harus dipertahankan, melainkan mengosongkan diri-Nya sendiri, dan dalam keadaan sebagai manusia, Ia telah mengosongkan diri-Nya dan taat sampai mati, bahkan sampai mati di kayu salib."

Kata 'mengosongkan diri,' yang digunakan dalam perikop ini dapat dipahami sebagai menyangkal diri, kontemplasi, mengambil posisi sebagai yang tidak menggunakan otoritas-Nya sebagai Anak Allah. Mengosongkan diri berarti melakukan ketaatan meski Ia harus mati karena-Nya. Puncak ketaatan itu adalah pada diri Yesus yang tersalib. Dengan demikian, seluruh substansi dari hidup berteologi harus berakar dan bertumbuh dalam teologi salib, dalam ritme keseluruhan diri Yesus yang telah mengosongkan diri-Nya, dalam penderitaan, kematian dan kebangkitan-Nya.

Tindakan 'mengosongkan diri' inilah yang rasanya harus sungguh-sungguh dihidupi oleh gereja dan banyak pelayan gereja. Sehingga dalam kehidupan sehari-hari, dalam relasi sosial satu sama lain, setiap orang dimampukan untuk tidak mendahulukan kekuasaan diri sendiri, kepentingan sendiri, tetapi mengosongkan diri untuk menemukan visi yang lebih besar dan lebih mulia dalam setiap persoalan realitas yang ada.

\section{Kerajaan Allah dan Hidup Baru}

Di dalam PBIK disebutkan bahwa "Kerajaan Allah itu adalah kuasa dan pemerintahan Allah yang menyelamatkan, yang tampak dan berwujud di dalam lingkungan dan suasana hidup yang di dalamnya terdapat kasih, kebenaran, keadilan, damai sejahtera, kesukacitaan, pemulihan dan pembaruan hidup (Mzr. 145:11-13, Mat. 9:35; Luk. 4:21; 4:43; Rm 14:7, 1 Kor. 4:20)." ${ }^{26}$ Pemahaman keyakinan ini mengacu pada pandangan bahwa kerajaan Allah sedang berlangsung dan masih akan digenapi hingga hari kedatangan Tuhan kembali. Oleh karena itu gereja dan seluruh orang percaya dipanggil untuk mewujudkan kehidupan yang selaras dengan kehendak Allah. Hal ini menegaskan bahwa gereja sendiri harus menjadi motor penggerak dalam mendorong orang percaya untuk bersunguh-sungguh menyatakan suara kenabiannya, sehingga setiap orang merasa terdorong dan dimampukan untuk berbuat dan berperilaku sebagaimana nilai-nilai ideal di atas. Di mana nilai-nilai itu harus menjadi cara hidup dari setiap orang percaya, sehingga oleh kuasa roh kudus setiap orang percaya mampu melakukannya.

\footnotetext{
${ }^{26}$ Persekutuan Gereja-gereja di Indonesia, Dokumen Keesaan Gereja Persekutuan Gereja-gereja di Indonesia (DKG-PGI), 110.
} 
Menjadi pertanyaan, mungkinkah gereja mampu menjadi saksi yang benar dalam setiap pemberitaannya, tanpa gereja itu sendiri menjadi yang pertama dalam realitas hidup sehari-hari melakukan kasih, kebenaran, keadilan, damai sejahtera, kesukacitaan, pemulihan dan pembaharuan hidup? Oleh karena itu, untuk menghadirkan syalom kerajaan Allah di bumi Indonesia, maka hal pertama yang sangat penting dan harus berbenah diri adalah gereja itu sendiri. Tanpa itu, gereja dan komunitas orang percaya tidak memiliki kekuatan, sahala, membuat orang lain mendengarnya.

\section{Gereja}

Secara tegas, PBIK menuliskan bahwa di dalam gereja," Kristus adalah Tuhan dan Kepala," (Ef. 4:3-16; Why. 7:9). Di dalam sejarah kekristenan dunia pada akhir abad ke 16 dan awal abad ke 17, terdapat masa di mana otoritas para pemimpin gereja, kaum klerus bertindak melampaui kuasa dan otoritas yang diberikan padanya oleh Tuhan Allah. Dalam hal ini disebutkan tentang pengampunan dosa yang seyogianya dan seharusnya merupakan otoritas Tuhan Allah, tetapi telah didorong menjadi tugas para imam, hingga munculnya istilah papa Deust. ${ }^{27}$ Secara khusus kondisi demikian telah mendorong bangkitnya protes dari banyak kalangan dan dipelopori oleh Martin Luther dan kawan-kawan. Berbagai ketegangan kemudian mendorong terjadinya skisma dan lahirlah persekutuan orang-orang yang menyebut dirinya Protestan.

Sejujurnya, tidak ada yang salah dengan pernyataan itu, bahwa Kristus adalah Tuhan dan Kepala. Meski peristiwa itu telah lama berlalu, namun cara-cara hidup beragama sebagaimana dulu itu terjadi, ternyata masih tetap mewarnai kehidupan bergereja hingga sekarang ini. Dalam kenyataan sekarang ini, tidak sedikit pendeta yang cenderung memahami jabatan pendeta sebagai otoritas dan hak istimewa (privilege) untuk memerintah. Sengaja atau tidak, kondisi-kondisi seperti itu terekam dalam Tata Gereja, tidak terkecuali HKBP. Struktur gereja menjadi sangat hirarkis. Pada saat yang sama pemaknaan dan implementasi tentang panggilan dan tahbisan menjadi sangat longgar. Gereja pun tercederai.

Pandangan Martin Luther sangat menekankan bahwa di dalam tahbisan melekat ketaatan. ${ }^{28}$ Dalam konteks ini, jabatan pendeta seyogianya dilakukan dalam ketaatan kepada Kristus sebagai Kepala Gereja. Tidak ada jabatan khusus tanpa dalam ketaatan, sebab jika demikian, jabatan itu akan menjadi sangat anarkis dan liar. ${ }^{29}$

\section{Kesimpulan}

Dengan pembahasan di atas sangat diharapkan, pemahaman bersama terkait keesaan dalam karya dan aksi oikumenis dapat digaungkan. Pada akhirnya, menghidupi nilai-nilai keagamaan yang dianut akan membangun perilaku yang baik pada setiap

\footnotetext{
${ }^{27}$ Martin Luther, Three Treatises: The Babylonia Captivity of the Church, 341.

${ }^{28}$ Lee Maxwell, "Luther on the Calling of Ministry Ecclesiae" dalam Pittelco, Sherpherd of Church, ed. Frederic W. Baue, John W. Fenton, Eric C. Forss, Frank J. Pies, and John T. Pless (Indiana, USA: Concordia Theological Summary Press, 2002), 167-170.

${ }^{29}$ Siagian, Gereja dan Kekuasaan: Menuju Eklesiologi HKBP yang Kontekstual, 36-37.
} 
orang. Terlepas dari apa keyakinan keagamaannya, bahkan orang-orang yang berbeda agama sekalipun dimungkinkan untuk membangun persekutuan dalam kasih, persaudaran yang mencerminkan keadilan, kebenaran, damai sejahtera dan lain sebagainya. Teologi sahala dapat digunakan untuk membangun pemahaman bersama tentang Tuhan, manusia, alam dan lain sebagainya, dengan penekanan bahwa setiap orang harus menghidupi keyakinan keagamaannya. Maka sahala sebagai karisma plus atau wibawa plus akan menjadi sesuatu yang diminati dan diharapkan terus terbentuk dan menjadi pengikat dalam relasi sosial satu sama lain, secara khusus dalam konteks masyarakat Indonesia yang multi kultural.

\section{Referensi}

Gertz, Clifford. The interpretation of Culture, USA: Basic Books, 1973.

Luther, Martin. Three Treatises: The Babylonia Captivity of the Church, translated by

A.T.W Steinhauser, revised by Frederick C. Ahrens and Abdel Ross Wentz, vol.

36, Philadelpia: Fortress Press, 1959.

Hadiwijono, Harun. Sari Sejarah Filsafat Barat, Yogyakarta: Kanisius, 1980.

Huria Kristen Batak Protestan, Almanak HKBP, Pearaja Tarutung: Kantor Pusat HKBP 2019

Huria Kristen Batak Protestan, Pengakuan Iman HKBP: Konfesi 1951 \& 1996, Pearaja Tarutung: Kantor Pusat HKBP, 2000.

Maxwell, Lee. "Luther on the Calling of Ministry Ecclesiae" dalam Pittelco, Sherpherd of Church, ed. Frederic W. Baue, John W. Fenton, Eric C. Forss, Frank J. Pies, and John T. Pless, Indiana, USA: Concordia Theological Summary Press, 2002.

Parkin, Harry. Batak Fruit of Hindu Thought

Persekutuan Gereja-gereja di Indonesia, Dokumen Keesaan Gereja Persekutuan Gereja-gereja di (DKG-PGI), Jakarta: BPK Gunung Mulia, 2015.

Russel, Letty M. Growth in Partnership, Philadelphia: Westminster Press, 1981

Siagian, Riris Johanna. Agama, Spiritualitas Kepemimpinan, Gereja dan Masyarakat, Pematangsiantar: Lembaga Bina Warga HKBP dan Sekolah Pendeta HKBP, 2019

Siagian, Riris Johanna. Gereja dan Kekuasaan: Menuju Eklesiologi HKBP yang Kontekstual, Pematangsiantar: Lembaga Bina Warga HKBP dan Sekolah Pendeta HKBP, 2017.

Siagian, Riris Johanna. Sahala Bagi Pemimpin: Dulu dan Kini, Pematangsiantar: Lembaga Bina Warga HKBP dan Sekolah Sekolah Pendeta HKBP dan STTHKBP, 2018.

Sinaga, Anicetus B. Allah Tinggi Batak Toba, Yogyakarta: Kanisius, t.th. Weber, Max Economy and Society, London: University of California Press, 1925/1978 